\title{
Linking integrated reporting quality with sustainability performance and financial performance in South Africa
}

\begin{tabular}{|c|c|}
\hline \multicolumn{2}{|c|}{$\begin{array}{l}\text { Authors: } \\
\text { Nadia Mans-Kemp }{ }^{1} \\
\text { Cornelis T. van der Lugt }{ }^{2}\end{array}$} \\
\hline \multicolumn{2}{|c|}{$\begin{array}{l}\text { Affiliations: } \\
{ }^{1} \text { Department of Business } \\
\text { Management, Faculty of } \\
\text { Economic and Management } \\
\text { Sciences, Stellenbosch } \\
\text { University, Stellenbosch, } \\
\text { South Africa }\end{array}$} \\
\hline \multicolumn{2}{|c|}{$\begin{array}{l}\text { University of Stellenbosch } \\
\text { Business School, Faculty of } \\
\text { Economic and Management } \\
\text { Sciences, Stellenbosch } \\
\text { University, Cape Town, } \\
\text { South Africa }\end{array}$} \\
\hline \multicolumn{2}{|c|}{$\begin{array}{l}\text { Corresponding author: } \\
\text { Nadia Mans-Kemp, } \\
\text { nadiamans@sun.ac.za }\end{array}$} \\
\hline \multicolumn{2}{|c|}{$\begin{array}{l}\text { Dates: } \\
\text { Received: } 13 \text { Feb. } 2020 \\
\text { Accepted: } 05 \text { May } 2020 \\
\text { Published: } 20 \text { Aug. } 2020\end{array}$} \\
\hline \multicolumn{2}{|c|}{$\begin{array}{l}\text { How to cite this article: } \\
\text { Mans-Kemp, N. \& Van der } \\
\text { Lugt, C.T., 2020, 'Linking } \\
\text { integrated reporting quality } \\
\text { with sustainability } \\
\text { performance and financial } \\
\text { performance in South Africa', } \\
\text { South African Journal of } \\
\text { Economic and Management } \\
\text { Sciences 23(1), a3572. } \\
\text { https://doi.org/10.4102/ } \\
\text { sajems.v23i1.3572 }\end{array}$} \\
\hline \multicolumn{2}{|c|}{$\begin{array}{l}\text { Copyright: } \\
\text { @ 2020. The Authors. } \\
\text { Licensee: AOSIS. This work } \\
\text { is licensed under the } \\
\text { Creative Commons } \\
\text { Attribution License. }\end{array}$} \\
\hline \multicolumn{2}{|l|}{ Read online: } \\
\hline 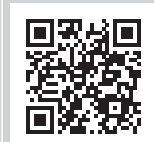 & $\begin{array}{l}\text { Scan this QR } \\
\text { code with your } \\
\text { smart phone or } \\
\text { mobile device } \\
\text { to read online. }\end{array}$ \\
\hline
\end{tabular}

Background: Ten years have elapsed since the launch of the International Integrated Reporting Council. Stakeholders increasingly question whether integrated reporting (IR) meets the objectives of decision-usefulness and accountability.

Aim: The primary objective of this study was to assess the usefulness of IR by examining the interrelations between the integrated reporting quality (IRQ), sustainability performance and financial performance of listed companies in South Africa.

Setting: The study is conducted in the country where integrated reporting is most established. The links between the IRQ of the Top 100 companies listed on the Johannesburg Stock Exchange and their environmental, social and corporate governance (ESG) scores and multiple financial indicators are investigated over the period 2013-2018.

Methods: The EY Excellence in Integrated Reporting Awards was used as a metric to determine the sample companies' IRQ. These awards were ranked according to four categories, namely 'progress to be made', 'average', 'good' and 'excellent'. Sustainability (ESG scores), as well as financial performance data (accounting-based and market-based variables) were sourced from Bloomberg. The panel data set was analysed by conducting a mixed-model analysis of variance and panel regressions.

Results: A high level of IRQ was found to be significantly associated with high levels of ESG performance, as well as high earnings per share and high leverage.

Conclusion: It appears that IR strengthens managerial efficiency and legitimacy in the eyes of debt capital providers in South Africa, while equity capital providers do not provide a clear signal of approval.

Keywords: Integrated reporting; sustainability performance; financial performance; legitimacy theory; stakeholder theory.

\section{Introduction}

Several accounting scandals and the global financial crisis during the 2000s contributed to the growing criticism of siloed annual financial and sustainability reporting (García-Benau, SierraGarcia \& Zorio 2013; Jennings 2003). Siloed reporting arguably does not provide a holistic picture of a company's sustainability and financial performance (Slack \& Campbell 2016), resulting in questions being raised about the reporting narrative of listed companies. Reporting fragmentation makes it furthermore challenging for investors to discern the true drivers of value creation (Klasa 2018). As the digital revolution demands more sophisticated corporate communication on material topics, a new reporting model was required, covering strategic content that reflects the interrelation between businesses, society, the economy and ecology (Klasa 2018; Slack \& Campbell 2016).

The International Integrated Reporting Council (IIRC 2013) has been aiming to embed integrated thinking in mainstream business practice since 2010. Their vision was facilitated by introducing a set of integrated reporting (IR) principles as the corporate reporting norm. By 2019, close to 2000 organisations, predominantly listed companies, in over 70 countries, including South Africa, were applying these principles (IIRC 2019). However, some thought leaders and researchers are critical about the evolution of corporate reporting, especially as IR is only well established in a limited number of countries (Adams 2015; De Villiers \& Sharma 2017). It could be argued that IR still has to prove whether it truly offers quality information that enhances decision-usefulness, in line with a key objective of the IIRC's Framework (IIRC 2013). The accountability for a broad base of capitals 
should furthermore not only enable the prediction of cash flows, but should also cover sustainable value creation and the responsible use of diverse resources (IIRC 2013).

Based on its democratic transition in the 1990s, South Africa is seen as a pioneer in both modern-day corporate governance standards (Armstrong, Segal \& Davis 2005) and IR (Simnett \& Huggins 2015). The King Reports on Corporate Governance have tracked the evolution of non-financial reporting and progressively recommended that South African companies should produce sustainability (King II) and integrated reports (King III and IV). The target audience of IR is the providers of financial capital, namely investors and lenders (IIRC 2013). Complex issues such as externalities and intangible assets that are not reflected in conventional financial statements can be addressed in integrated reports (IIRC 2013).

Since 2010, companies listed on the Johannesburg Stock Exchange (JSE) are expected to publish integrated reports. Initial reaction from the local investor community signalled their approval, especially as valuable information is provided, which can enhance decision-making (Atkins \& Maroun 2015). In a recent international comparison of the integrated reporting quality (IRQ) of ten G20 countries, South Africa received the top ranking (Eccles, Krzus \& Solano 2019). Furthermore, there is a growing body of research on IR in South Africa. Although previous researchers have compared companies' annual reports, sustainability reports and their integrated reports (Du Toit, Van Zyl \& Schutte 2017; Setia et al. 2015; Solomon \& Maroun 2012), the links between reporting quality, sustainability indicators and financial indicators (including leverage) and IRQ have not consistently been assessed.

As creditors are likely to request more transparent information from more leveraged companies (Dilling \& Caykoylu 2019), the inclusion of financial leverage (henceforth referred to as leverage) might have a significant impact on IR studies. Leverage denotes the percentage debt that is used to fund total assets (Chang 2016). It should be taken into account that debt usage can have a considerable impact on the variability in both profitability and earnings per share (EPS) (Chang 2016). Previous scholars mainly assessed IRQ by applying the IIRC framework and by employing the EY Excellence in Integrated Reporting Awards (Barth et al. 2017; De Villiers, Venter \& Hsiao 2017b).

Given the identified gap in the literature, the authors examined the linkages between IRQ and the sustainability and financial performance of the JSE Top 100 companies over the period 2013-2018. The objectives were twofold, namely to investigate differences in the IRQ of the considered companies, and to explore the links between the companies' IRQ and various sustainability and financial considerations. The categorised EY Excellence in Integrated Reporting Awards was used to assess the companies' IRQ. The usage of these rankings enabled the authors to consider so-called 'reference reporters', namely those that received recognition through an award scheme (Lopes \& Coelho 2018). Accounting and market-based financial and sustainability data - environmental, social and corporate governance(ESG) scores-were sourced from Bloomberg (2019). Mixed-model analysis of variance (ANOVA) tests were conducted to investigate significant differences across the EY reporting categories ('progress to be made', 'average', 'good' and 'excellent'), while panel regressions were employed to assess the links between the considered companies' IRQ and sustainability and financial considerations. The results revealed that a high level of IRQ was significantly related to a high level of ESG performance, as well as high EPS and leverage. Companies that had good ESG performance scores were arguably in a better position to produce high-quality IR than those with poor sustainability performance. The companies with better financial performance seemed to receive more market recognition.

The theoretical framework is presented next, accompanied by an overview of relevant studies that were considered in developing the hypotheses. Thereafter, the data collection and analysis are discussed, followed by the findings. Conclusions and recommendations are offered for practitioners, investors and researchers.

\section{Theoretical framework and hypotheses development}

The literature review indicates that research on corporate reporting typically either pursues legitimacy or economic viewpoints. Alrazi, De Villiers and Van Staden (2015) argued that legitimacy is conditional on public evaluation of company performance and reporting. Legitimacy theory could be used to offer a societal perspective, or to reflect different stakeholders' views, industry standards or institutional norms (Deegan \& Unerman 2011) that are linked to reporting a company's licence to operate (Burlea-Schiopoiu \& Popa 2013; Demuijnck \& Fasterling 2016). This theory has been employed by several authors who investigated IR (Adams et al. 2016; Ahmed Haji \& Anifowose, 2017; De Villiers, Hsiao \& Maroun 2017a; Setia et al. 2015; Van Bommel 2014). A company could arguably use IR to justify its existence through legitimising actions (BurleaSchiopoiu \& Popa 2013) in an attempt to boost its reputation (Higgins, Stubbs \& Love 2014).

Companies that have a considerable negative external impact are likely to provide more detailed integrated reports to legitimise their business than those with minor environmental implications (Buitendag, Fortuin \& De Laan 2017). Disclosure could thus be used to communicate corporate behavioural changes in an attempt to 'repair' poor legitimacy (Suchman 1995). The question arises whether external communication reflects internal adjustments as part of a proactive legitimacy strategy (Alrazi et al. 2015; Lindblom 2010), or whether it is a symbolic presentation that confirms a 'greenwashing view' of legitimacy theory (Mahoney et al. 2013). As managers influence the external perceptions of their companies through communication strategies, concerns have been raised that voluntary reporting is often used as a mere symbolic 'legitimation practice' (Lai, Melloni \& Stacchezzini 2016). 
Malola and Maroun (2019) reported that most disclosures by South African companies are still symbolic rather than substantive.

The IIRC (2013) envisioned that IR could improve managerial efficiency by providing reliable information that is relevant for long-term value creation. Some authors therefore argued that the development of a business case for IR is essential to enhance its wider uptake (Adams 2015; Burke \& Clark 2016; Simnett \& Huggins 2015). De Villiers, Rinaldi and Unerman (2014), however, cautioned against a dominant focus on economic value creation at the cost of non-financial resources. It is thus essential to investigate the links between multiple capital resources and IRQ. Sustainability disclosure, depending on multiple tangible and intangible organisational features, might be a substantive legitimacy tool (Cho \& Patten 2007; Mahoney et al. 2013; Stolowy \& Paugam 2018). The combination of legitimacy theory and market efficiency paves the way for an assessment of organisational features (including sustainability and financial performance) as determinants of IRQ (De Villiers et al. 2017a).

Whereas most IR studies have centred on normative arguments, more research is required on IR practices (Cheng et al. 2014; Dumay et al. 2016). Sustainability and financial performance as determinants of IRQ highlight the prospect of IR being used as an instrument to address a company's poor performance in an attempt to restore legitimacy. In the international context, Melloni, Caglio and Perego (2017) found that the integrated reports of companies with inadequate social and financial performance tended to be significantly longer and less balanced. Another essential financial consideration is leverage, as lenders are demanding more transparent disclosure from highly leveraged companies (Lai et al. 2016). Companies in need of external funding will arguably be more likely to disclose information than those with sufficient internal funds (Dilling \& Caykoylu 2019). Lopes and Coelho (2018) suggested that companies with a high level of IRQ tend to be large, profitable and less leveraged.

Responsible investors are furthermore interested in whether IR is associated with better ESG management. De Villiers et al. (2017b) thus suggested that the relationship between IR and corporate value should be assessed, while controlling for ESG. Churet and Eccles (2014) found a positive relationship between the effective management of ESG issues and IR. They argued that the quality of ESG management will eventually reflect in the company's financial performance. Several authors focused on the economic consequences of IR in South Africa, given the country's front-runner status pertaining to IR. A summary of the findings of authors who applied the IIRC framework as a normative checklist for the quality of corporate reporting in South Africa is provided in Table 1.

TABLE 1: Summary of studies on corporate reporting in South Africa.

\begin{tabular}{|c|c|c|c|}
\hline Authors & Companies and years & Reporting measure & Main findings \\
\hline $\begin{array}{l}\text { Marcia, Maroun and } \\
\text { Callaghan (2015) }\end{array}$ & $\begin{array}{l}82 \text { JSE-listed firms; } \\
2011-2012\end{array}$ & $\begin{array}{l}\text { Corporate responsibility reporting: level } \\
\text { of disclosure; text analysis of reports with } \\
\text { ESG checklist based on King III and the } \\
\text { requirements of the Global Reporting } \\
\text { Initiative (GRI). }\end{array}$ & $\begin{array}{l}\text { No significant link was found between share value and corporate } \\
\text { responsibility reporting. Possible explanations include weakness of early-stage } \\
\text { IRQ and failure to link IRQ with ESG and financial performance. }\end{array}$ \\
\hline Lee and Yeo (2016) & $\begin{array}{l}822 \text { JSE firm-year } \\
\text { observations; 2010-2013 }\end{array}$ & $\begin{array}{l}\text { Constructed a composite integrated } \\
\text { reporting score by assigning equal weights } \\
\text { to each of the eight content elements of } \\
\text { the IIRC's framework. }\end{array}$ & $\begin{array}{l}\text { A significant positive association was found between firm valuation (Tobin's Q, } \\
\text { risk-adjusted returns; return on assets) and IRQ. The link was stronger in } \\
\text { complex companies (i.e. large companies with considerable intangible assets). } \\
\text { When focusing on companies with higher external financing needs, those that } \\
\text { had a higher IRQ also had higher firm valuations. }\end{array}$ \\
\hline $\begin{array}{l}\text { Baboukardos and Rimmel } \\
\text { (2016) }\end{array}$ & $\begin{array}{l}85 \text { listed firms: } 2008-2010 \\
\text { (pre-King III); 2011-2013 } \\
\text { (post-King III) }\end{array}$ & $\begin{array}{l}\text { Considered whether companies published } \\
\text { integrated reports; ESG Thomson Reuters } \\
\text { ASSET4 sustainability disclosure scores. }\end{array}$ & $\begin{array}{l}\text { An increase was found in the earnings' valuation coefficient, but the value } \\
\text { relevance of net assets decreased. The latter result could be ascribed to risks } \\
\text { or so-called 'unbooked' liabilities that were revealed or measured more } \\
\text { reliably after the introduction of IR. }\end{array}$ \\
\hline Barth et al. (2017) & $\begin{array}{l}\text { JSE-listed firms assessed } \\
\text { by EY; 2011-2014 }\end{array}$ & $\begin{array}{l}\text { Twelve components, based on the IRRC } \\
\text { framework's principles and content } \\
\text { elements; mean scores based on the } \\
\text { criteria used to determine the EY } \\
\text { Excellence in Integrated Reporting Awards. }\end{array}$ & $\begin{array}{l}\text { A significant positive relationship was found between IRQ and firm value } \\
\text { (Tobin's Q). The link was largely attributed to liquidity and expected future } \\
\text { cash flows, and not cost of capital. }\end{array}$ \\
\hline $\begin{array}{l}\text { Zhou, Simnett and Green } \\
\text { (2017) }\end{array}$ & $\begin{array}{l}132 \text { JSE-listed companies; } \\
\text { 2009-2012 }\end{array}$ & $\begin{array}{l}\text { Level of alignment with the IIRC } \\
\text { framework, measured as the total } \\
\text { disclosure score based on a coding } \\
\text { framework validated by an investor } \\
\text { survey. }\end{array}$ & $\begin{array}{l}\text { Analyst forecast errors decreased as the level of alignment of reports with the } \\
\text { IIRC framework increased. The improved alignment was associated with a } \\
\text { subsequent decrease in the cost of equity, mainly for companies with a lower } \\
\text { analyst following. Companies with a high analyst following had higher IR } \\
\text { disclosure scores, were large companies with a lower book-to-market ratio } \\
\text { and were more leveraged. }\end{array}$ \\
\hline Bernardi and Stark (2018) & $\begin{array}{l}41 \text { JSE-listed firms from } \\
\text { eight sectors; 2008-2012 }\end{array}$ & $\begin{array}{l}\text { ESG scores pre- and post-mandatory } \\
\text { integrated reporting; Bloomberg's } \\
\text { total and individual ESG scores. }\end{array}$ & $\begin{array}{l}\text { Environmental impact disclosure was associated with better forecast accuracy } \\
\text { after the introduction of mandatory IR. The association between analyst } \\
\text { forecast accuracy and governance disclosure improved after the introduction } \\
\text { of the IR regime. The results were applicable mostly to companies outside the } \\
\text { financial services sector. }\end{array}$ \\
\hline $\begin{array}{l}\text { Horn, De Klerk and De } \\
\text { Villiers (2018) }\end{array}$ & $\begin{array}{l}65 ; 75 ; 73 \text { large JSE-listed } \\
\text { firms; 2008; 2011; } 2013\end{array}$ & $\begin{array}{l}\text { Six measures for corporate social } \\
\text { responsibility reporting based on KPMG's } \\
\text { International Survey of Corporate } \\
\text { Responsibility Reporting. }\end{array}$ & $\begin{array}{l}\text { No significant link was found between corporate social responsibility } \\
\text { disclosure and firm value (Tobin's Q), but a positive association was confirmed } \\
\text { between GRI and firm value for companies listed on the Socially Responsible } \\
\text { Investment Index. }\end{array}$ \\
\hline
\end{tabular}

Note: Please see the full reference list of this article: Mans-Kemp, N. \& Van der Lugt, C.T., 2020, 'Linking integrated reporting quality with sustainability performance and financial performance in South Africa', South African Journal of Economic and Management Sciences 23(1), a3572. https://doi.org/10.4102/sajems.v23i1.3572, for more information.

ESG, environmental, social and corporate governance; GRI, Global Reporting Initiative; IIRC, International Integrated Reporting Council; IR, integrated reporting; IRQ, integrated reporting quality, JSE, Johannesburg Stock Exchange. 
Perusal of Table 1 highlights several key points. After 10 years of experimenting with the IIRC framework, the content analysis of integrated reports still needs to move beyond considering the quantity of disclosure and compliance with core content elements towards closer examination of reporting quality and applying the IIRC's (2013) principles (including strategic focus, materiality and conciseness). Contrasting results were reported on the link between financial performance and IRQ. Some authors reported a positive association between IRQ and firm value (Barth et al. 2017; Lee \& Yeo 2016), lower cost of equity capital (Zhou et al. 2017), higher return on assets (ROA) and sales growth (Lee \& Yeo 2016). Other authors highlighted a lack of significant evidence that links IRQ with firm value (Buitendag et al. 2017; Horn et al. 2018; Marcia et al. 2015) and with profitability (Buitendag et al. 2017). In light of these contradictory findings, as well as the identified gap to account for a company's ESG performance and leverage, the following hypotheses were formulated:

$\mathbf{H}_{\mathrm{A}^{\prime} 1}$ : There is a positive relationship between the sustainability performance and the IRQ of the considered JSE-listed companies over the period 2013-2018.

$\mathrm{H}_{\mathrm{A}^{\prime} 2}$ : There is a positive relationship between the financial performance and the IRQ of the considered JSE-listed companies over the period 2013-2018.

$\mathrm{H}_{\mathrm{A}^{\prime} 3}$ : There is a positive relationship between leverage and the IRQ of the considered JSE-listed companies over the period 2013-2018.

It should be noted that a high level of sustainability performance does not automatically translate into a high level of IRQ. A company might obtain high ESG scores for its sustainability performance and publish a good-quality sustainability report, yet fail at integrated thinking and publishing a high-quality integrated report. As a result, the association between sustainability performance and IRQ (the first hypothesis) was assessed. Given the interrelation between financial performance and managerial decisionmaking on leverage (Jermias 2008), the second and third hypotheses tested the considered companies' external efficiency (recognition for financial performance) and internal managerial efficiency (capturing and communicating decision-useful information by displaying accountability to capital providers).

\section{Research design and methodology}

The EY Excellence in Integrated Reporting Awards that were allocated to the JSE Top 100 companies was used as a measure of IRQ over the period 2013-2018. The considered companies accounted for approximately $95 \%$ of the bourse's market capitalisation (EYGM Ltd. 2017). The majority of the awardees did business in the financial and the basic materials sectors.

The EY scoring system is based on the IIRC framework's content elements and guiding principles, as well as its fundamental concepts (i.e. value creation and the six capitals) (EYGM Ltd. 2017). The EY award categories were coded as follows for the purpose of this study: 'progress to be made', henceforth 'progress' (1), 'average' (2), 'good' (3) and 'excellent' (4). Over the study period, 119 progress, 113 average, 176 good and 172 excellent awardees were considered. An advantage of using an external source to assess IRQ is that the evaluators are independent (De Villiers et al. 2017b). Weaknesses, however, include that a limited number of large companies are evaluated by EY, possible subjectivity of the evaluators, differences in their interpretations of the IIRC framework and a lack of clarity concerning cut-off points between different evaluation categories (De Villiers et al. 2017b). Although the limitations of EY's methodology were acknowledged in this study, the use of an established rating scheme contributed to the reliability and validity of the findings.

The financial variables (Table 2) were sourced from Bloomberg (2019) for the corresponding financial year on which the EY Awards were based. Several of these variables were suggested by previous authors (see Table 1). Both the individual and composite ESG scores computed by Bloomberg (2019) were used as proxies for sustainability performance. These scores reflect analysts' evaluation of the companies' ESG disclosure and served as a measure of the companies' management engagement towards sustainability (Eccles, Serafeim \& Krzus 2011).

A descriptive analysis was conducted to determine trends based on the four IRQ rankings. A mixed-model ANOVA

TABLE 2: Measurement of the sustainability and financial variables.

\begin{tabular}{|c|c|}
\hline Variable $\dagger$ & Measurement \\
\hline $\begin{array}{l}\text { Composite environmental, social and } \\
\text { corporate governance (ESG) score }\end{array}$ & $\begin{array}{l}\text { Proprietary Bloomberg score based on the } \\
\text { extent of a company's ESG disclosure; } \\
\text { maximum score: } 100\end{array}$ \\
\hline Environmental $(\mathrm{E})$ score & $\begin{array}{l}\text { Proprietary Bloomberg score based on the } \\
\text { extent of a company's environmental } \\
\text { disclosure; maximum score: } 100\end{array}$ \\
\hline Social (S) score & $\begin{array}{l}\text { Proprietary Bloomberg score based on the } \\
\text { extent of a company's social disclosure; } \\
\text { maximum score: } 100\end{array}$ \\
\hline Corporate governance (G) score & $\begin{array}{l}\text { Proprietary Bloomberg score based on the } \\
\text { extent of a company's governance } \\
\text { disclosure; maximum score: } 100\end{array}$ \\
\hline Return on assets (ROA); winsorised & $\begin{array}{l}\text { Net operating profit divided by average } \\
\text { total assets }\end{array}$ \\
\hline Total share return (TSR); $\log 10$ & $\begin{array}{l}\text { Bloomberg's total return index based on } \\
\text { gross dividends }\end{array}$ \\
\hline Earnings per share (EPS); winsorised & $\begin{array}{l}\text { Net income available for common } \\
\text { shareholders divided by the weighted } \\
\text { average shares outstanding }\end{array}$ \\
\hline Dividend per share (DPS); $\log 10$ & $\begin{array}{l}\text { Dividend distributed to common } \\
\text { shareholders divided by the weighted } \\
\text { average shares outstanding }\end{array}$ \\
\hline Tobin's Q & $\begin{array}{l}\text { Market value of company to replacement } \\
\text { cost of assets: (market capitalisation }+ \\
\text { total liabilities + preferred equity }+ \\
\text { minority interest) divided by total assets }\end{array}$ \\
\hline Market-to-book ratio & $\begin{array}{l}\text { Market capitalisation divided by book } \\
\text { value }\end{array}$ \\
\hline Market capitalisation; $\log 10$ & $\begin{array}{l}\text { Total current market value of outstanding } \\
\text { shares }\end{array}$ \\
\hline Leverage & (Total debt divided by total assets) $\times 100$ \\
\hline Weighted average cost of capital (WACC) & $\begin{array}{l}\text { [cost of debt x (total debt/total capital)] + } \\
\text { [cost of preference shares } x(\text { preference } \\
\text { shares/total capital)] + [cost of equity x } \\
\text { (equity capital/total capital)] }\end{array}$ \\
\hline
\end{tabular}

Source: Authors' own work based on the definitions by: Bloomberg, L.P. 2019. Research domain. Software and database. New York, NY.

$\dagger$, Values were downloaded in million rand where applicable. Given the outliers, a number of variables were winsorised and logs were used in some instances. 
analysis was then employed to test for significant differences between rankings over the research period. The restricted maximum likelihood method was used to estimate variance components. The Fisher's least significant difference (LSD) test was used to test pair-wise comparisons to determine where the differences occurred. Given the panel nature of the dataset, the F-test and the Hausman test were used to determine whether a fixed or random effects regression model was most suitable for the respective regression analyses. An unbalanced panel design was used, as the compilation of the Top 100 companies differed on an annual basis depending on their market capitalisation.

The following fixed effects regression model was applied to test $\mathrm{H}_{\mathrm{A}, 1}$ :

$\mathrm{IRQ}_{i t}=\beta_{0 i}+\beta_{1} \mathrm{ESG}_{i t}+\beta_{2} \mathrm{E}_{i t}+\beta_{3} \mathrm{~S}_{i t}+\beta_{4} \mathrm{G}_{i t}+\beta_{5}$

Market capitalisation $_{i t}+\delta_{\mathrm{t}}+\epsilon_{i t}$

[Eqn 1]

Note that a dummy variable was included for each time period.

The following fixed effects regression model was applied to test $\mathrm{H}_{\mathrm{A}, 2}$ :

$\mathrm{IRQ}_{i t}=\beta_{0 i}+\beta_{1} \mathrm{EPS}_{i t}+\beta_{2} \mathrm{DPS}_{i t}+\beta_{3} \mathrm{TSR}_{i t}+\beta_{4}$ Tobin's $\mathrm{Q}_{i t}+\beta_{5}$

Market - to - book $_{i t}+\beta_{6} \mathrm{ROA}_{i t}+\beta_{7}$

Market capitalisation $_{i t}+\delta_{\mathrm{t}}+\epsilon_{i t}$

[Eqn 2]

Note that a dummy variable was included for each time period.

The following random effects regression model was used to test $\mathrm{H}_{\mathrm{A}, 3}$ :

$\mathrm{IRQ}_{i t}=\beta_{0}+\beta_{1}$ Leverage $_{i t}+\beta_{2} \mathrm{WACC}_{i t}+\beta_{3}$

Market capitalisation $_{i t}+\mu_{i}+\omega_{t}+\epsilon_{i t}$

[Eqn 3]

The Breusch-Pagan Lagrange multiplier was used to test for heteroskedasticity and the results were adjusted where applicable. Given that only publicly available data were used, the research ethics committee of the authors' affiliated university exempted the study from an ethics review. Pertaining to multicollinearity, acceptable variance inflation factor values ( 5 or below) were determined for the financial variables. Given the stated Bloomberg (2019) methodology (refer to Table 2) to compile both the composite and the individual ESG scores, these scores were highly correlated. As the composite ESG score might not reflect the true extent of the companies' individual ESG performance, the individual scores were also incorporated in separate regression analyses.

\section{Ethical consideration}

This project (number ONB-2019-10138) was exempted from ethics review and clearance by the Research Ethics Committee (REC), Stellenbosch University, on 17 June 2019.

\section{Findings and discussion}

In this section, the descriptive results are discussed for the financial indicators and the ESG scores of the companies ranked according to the four EY categories. This discussion is followed by the presentation of the inferential findings.

\section{Descriptive results}

Table 3 provides the descriptive results.

As shown in Table 3, the companies in the highest two IRQ categories had the highest composite ESG scores. The companies that were more sustainable than their peers were better sustainability reporters and were familiar with the GRI's reporting guidelines. As a result, they were arguably in a better position to apply the IIRC's (2013) guidelines including improved connectivity between sustainability and financial performance. The average composite ESG scores were, however, relatively low (below 50 out of 100 for all four IRQ categories). This low level of compliance led to the question whether a company's sustainability could be deemed a mediating factor in determining the effectiveness of IR, as suggested by Bernardi and Stark (2018).

As composite ESG scores could conceal differing degrees of disclosure on specific sustainability aspects, the individual ESG scores were also considered. The comparatively higher governance scores could be ascribed to South Africa's advanced corporate governance system. Before the advent of IR, asset managers highlighted inadequate environmental disclosure by South African companies (Giamporcaro, Pretorius \& Visser 2010). The low mean environmental scores (in all four IRQ categories) suggest that the majority of the JSE Top 100 companies still experience difficulty to explain their impact and dependence on natural capital. According to Buitendag et al. (2017), environmentally sensitive companies tend to have higher levels of IRQ in comparison to companies with a limited negative environmental impact. The 10 companies that most consistently appeared in the top (excellent) IRQ category for the overall six-year review period included three mining companies, a petrochemical company and four financial services companies. The high IRQ of financial institutions, specifically banks, could be ascribed to the pressure from consumers to step up their accountability (Van Zijl, Wöstmann \& Maroun 2017).

Pertaining to financial performance, companies rated in the progress category were more profitable (mean ROA) than those companies in the excellent category (see Table 3). In contrast, companies in the excellent IRQ category had the highest mean EPS and dividends per share (DPS). Companies with the highest level of IRQ therefore rewarded their shareholders with higher dividends, despite the companies' comparably lower profitability. A possible explanation is that some companies that produced a quality integrated report arguably spent more money over the short term to address externalities, resulting in lower profitability, in an attempt to enhance sustainable value creation over the long term. 
TABLE 3: Descriptive statistics.

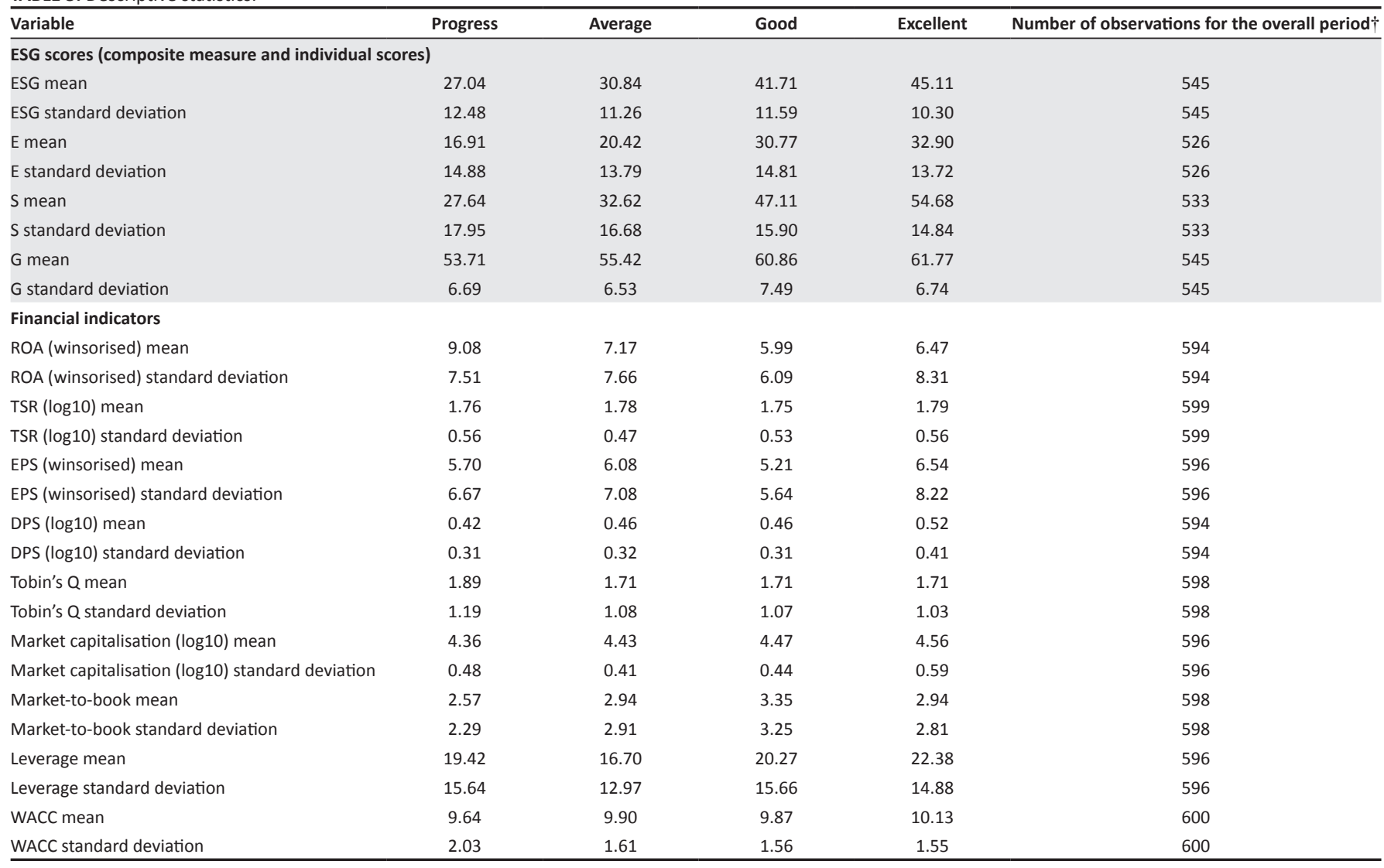

DPS, dividend per share; EPS, earnings per share; ESG, environmental, social and corporate governance; ROA, return on assets; TSR, total share return; WACC, weighted average cost of capital. $\dagger$, The ESG, financial and leverage data were not available for all companies.

TABLE 4: Mixed-model analysis of variance results.

\begin{tabular}{|c|c|c|c|c|c|c|}
\hline \multicolumn{2}{|l|}{ Variable } & \multirow[t]{2}{*}{ Effect } & \multirow{2}{*}{$\begin{array}{l}\text { Numerator degrees } \\
\text { of freedom }\end{array}$} & \multirow{2}{*}{$\begin{array}{c}\text { Denominator degrees } \\
\text { of freedom }\end{array}$} & \multirow[t]{2}{*}{$F$} & \multirow[t]{2}{*}{$p$} \\
\hline Type & Performance criteria & & & & & \\
\hline \multirow[t]{8}{*}{ Sustainability indicators } & \multirow[t]{2}{*}{ ESG } & Year & 5 & 420 & $12.66 * * *$ & 0.00 \\
\hline & & Ranking & 3 & 476 & $9.78 * * *$ & 0.00 \\
\hline & \multirow[t]{2}{*}{ E } & Year & 5 & 403 & $5.23 * * *$ & 0.00 \\
\hline & & Ranking & 3 & 460 & $5.16 * * *$ & 0.00 \\
\hline & \multirow[t]{2}{*}{ S } & Year & 5 & 411 & $12.00 * * *$ & 0.00 \\
\hline & & Ranking & 3 & 486 & $11.77 * * *$ & 0.00 \\
\hline & \multirow[t]{2}{*}{ G } & Year & 5 & 428 & $2.11 *$ & 0.06 \\
\hline & & Ranking & 3 & 516 & $8.23 * * *$ & 0.00 \\
\hline \multirow[t]{18}{*}{ Financial indicators } & \multirow[t]{2}{*}{ ROA (winsorised) } & Year & 5 & 467 & $4.52 * * *$ & 0.00 \\
\hline & & Ranking & 3 & 562 & 1.05 & 0.37 \\
\hline & \multirow[t]{2}{*}{ TSR $(\log 10)$} & Year & 5 & 460 & $3.15^{* * *}$ & 0.01 \\
\hline & & Ranking & 3 & 523 & 0.80 & 0.49 \\
\hline & \multirow[t]{2}{*}{ Tobin's Q } & Year & 5 & 464 & $5.90 * * *$ & 0.00 \\
\hline & & Ranking & 3 & 553 & 0.94 & 0.42 \\
\hline & \multirow[t]{2}{*}{ EPS (winsorised) } & Year & 5 & 466 & 0.95 & 0.45 \\
\hline & & Ranking & 3 & 563 & 0.21 & 0.89 \\
\hline & \multirow[t]{2}{*}{ DPS $(\log 10)$} & Year & 5 & 457 & $4.26 * * *$ & 0.00 \\
\hline & & Ranking & 3 & 536 & 0.20 & 0.90 \\
\hline & \multirow[t]{2}{*}{ Market-to-book } & Year & 5 & 465 & $3.80 * * *$ & 0.00 \\
\hline & & Ranking & 3 & 557 & 0.69 & 0.56 \\
\hline & \multirow{2}{*}{$\begin{array}{l}\text { Market capitalisation } \\
\text { (log10) }\end{array}$} & Year & 5 & 461 & $8.24 * * *$ & 0.00 \\
\hline & & Ranking & 3 & 541 & 0.47 & 0.71 \\
\hline & \multirow[t]{2}{*}{ Leverage } & Year & 5 & 457 & 1.51 & 0.18 \\
\hline & & Ranking & 3 & 525 & $2.84 * *$ & 0.04 \\
\hline & \multirow[t]{2}{*}{ WACC } & Year & 5 & 468 & $5.40 * * *$ & 0.00 \\
\hline & & Ranking & 3 & 564 & $3.04 * *$ & 0.03 \\
\hline
\end{tabular}

DPS, dividend per share; EPS, earnings per share; ESG, environmental, social and corporate governance; ROA, return on assets; TSR, total share return; WACC, weighted average cost of capital.

*, Significant at the $10 \%$ level; **, Significant at the $5 \%$ level; ***, Significant at the $1 \%$ level. 
The mean market-based total share return (TSR) of those companies in the excellent IRQ category was the highest across the considered categories. In contrast, the average Tobin's $Q$ value for companies in the progress IRQ category was higher than those in the excellent category. As Tobin's $Q$ reflects growth opportunities, high values could encourage companies to invest more (Müller 2013). Since companies in the excellent IRQ category arguably had a better understanding of and disclosure on their asset values (including related opportunities and externalities), they seemed to pay a price for being more transparent about the replacement costs of their assets, resulting in comparatively lower Tobin's Q values.

The main differences between the market-to-book ratio and Tobin's $Q$ included that the former only incorporated the market and book values of equity, while the latter accounted for a company's total market and replacement values (see Table 2). It can be challenging to accurately determine replacement costs, specifically for companies with high levels of intangible assets. Despite the growing importance of intangible assets to obtain a competitive advantage, they are often not adequately disclosed (Pucci et al. 2014). In their analysis of reporting by JSE-listed companies before and after the release of King III (which introduced IR), Baboukardos and Rimmel (2016) noted a decline in the value relevance of the companies' net assets over time. The authors attributed their finding to the so-called 'unbooked' liabilities that were revealed or measured more reliably after the introduction of IR. In line with the findings of Lee and Yeo (2016), the considered companies in the current study with the highest level of IRQ also had the highest leverage. These companies probably disclosed more relevant information in view of their higher liabilities.

\section{Accounting for differences in integrated reporting quality}

Given the considerable differences in the reported means of the ESG and financial variables as shown in Table 3, mixedmodel ANOVA and Fisher's LSD analyses were performed to investigate the significance of the observed trends. Year and ranking were considered as fixed effects, whereas the ticker codes were used as the random effect. The Kenward-Rogers degrees of freedom were applicable. The ANOVA results are reported in Table 4.

Inspection of Table 4 indicates significant differences between the IRQ ranking categories and the composite ESG score and the individual ESG scores over the review period. The Fisher LSD results furthermore showed significant differences between the lowest IRQ ranking (progress, average) and the highest ranking (good, excellent) Sustainability aspects (proxied by ESG) therefore played a considerable role in the observed fluctuations in the IRQ ranking categories. In contrast, by using a self-constructed IRQ measure, Malola and Maroun (2019) reported that environmental and social impact did not influence IRQ in South Africa. They added that external factors had contributed less to IRQ, whereas internal processes were becoming more relevant when reflecting on quantitative and qualitative considerations.

Pertaining to the financial indicators, significant differences occurred over the review period for all variables except EPS and leverage. However, significant ranking differences were only noted for leverage and weighted average cost of capital. The Fisher's LSD results revealed significant differences between the progress category and the other categories. Dilling and Caykoylu (2019) argued that companies in need of debt funding are more likely to disclose detailed information, possibly resulting in a higher IRQ. Consequently, capital usage played a considerable role in the observed fluctuations in IRQ. These results, however, warrant further investigation.

\section{Panel regression results}

The regression results for IRQ and ESG performance are shown in Table 5.

While significant positive relationships are noted between the individual ESG scores and IRQ in Table 5, the combined ESG score is significantly negatively related to IRQ. It is possible that the composite ESG score played a more important role for companies that were still making progress in improving their integrated reports, compared to those that already published high-quality integrated reports. It should be noted that the ESG scores only accounted for some of the six capitals of the IIRC's (2013) framework.

In an attempt to enhance the legitimacy of integrated reports (i.e. positive recognition by shareholders and other stakeholders), companies might report more extensively on a specific resource. Bernardi and Stark (2018) regarded the level of ESG disclosure as a mediating variable when determining the effectiveness of IR. Their results were largely ascribed to environmental and governance disclosures, instead of composite ESG scores. In addition, Buitendag et al. (2017) noted that companies with a more significant negative environmental impact focused more on environmental

TABLE 5: Regression analysis results for integrated reporting quality and environmental, social and corporate governance scores.

\begin{tabular}{lccccc}
\hline Variable & $\begin{array}{c}\text { Regression } \\
\text { coefficient }\end{array}$ & $\begin{array}{c}\text { Standard } \\
\text { error }\end{array}$ & $t$-value & $P r>|t|$ & $\begin{array}{c}t \text {-value adjusted for } \\
\text { heteroskedasticity }\end{array}$ \\
\hline ESG & -2.369 & 0.094 & $-2.108^{* *}$ & 0.04 & $-2.407 * *$ \\
E & 1.523 & 0.048 & $2.109 * *$ & 0.04 & $2.310^{* *}$ \\
S & 1.013 & 0.024 & $2.385 * *$ & 0.02 & $2.741^{* * *}$ \\
G & 0.358 & 0.023 & $2.159 * *$ & 0.03 & $2.367 * *$ \\
$\begin{array}{l}\text { Market } \\
\text { capitalisation } \\
\text { (log10) }\end{array}$ & -0.069 & 0.124 & -1.141 & 0.25 & -0.843 \\
\hline
\end{tabular}

Note: Adjusted $R$-squared: 0.21 ; the quality of fit of the regression model was significant fit of the model: $F 2.21 * ; d f 5,365$.

Preferred model: One-way fixed effects; test for fixed effects $(F): 12.14 * * *$; Hausman test for random effects $(F): 27.25 * * *$.

Breusch-Pagan heteroskedasticity: 260.21***

ESG, environmental, social and corporate governance.

*, Significant at the $10 \%$ level; **, Significant at the $5 \%$ level; ***, Significant at the $1 \%$ level. 
sensitivities in their integrated reports. South African companies are under considerable pressure to improve their actions and disclosures pertaining to social and environmental considerations. The results of this study, as can be seen in Table 5, highlight the importance of accounting for ESG aspects.

To account for multicollinearity, separate regression analyses were computed for IRQ and the composite ESG and IRQ and the individual ESG scores while controlling for company size (market capitalisation). A positive, but insignificant relationship was reported between IRQ and ESG ( $t: 1.624 ; p$ : 0.11$)$. Positive associations were also noted between IRQ and the individual environmental $(t: 0.102 ; p$ : $0.92), \mathrm{S}(t: 1.576 ; p: 0.12)$ and governance $(t: 0.430 ; p: 0.67)$ scores. Given that sustainability concerns differ across industries, separate regression analyses were also conducted for the combined basic materials and financials sectors (as most of the considered companies operated in these sectors) and the other combined sectors (industrials, consumer goods, technology, consumer services, telecommunications and healthcare; henceforth called 'other sectors'). The results revealed a significant positive relationship between IRQ and ESG $\left(t: 4.583^{* * *} ; p\right.$ : 0.00$)$ and IRQ and the social score $\left(t: 3.174^{* * *} ; p: 0.00\right)$ for the basic materials and financial sectors. Significant positive links were also reported between IRQ and ESG $\left(t: 1.631^{*} ; p: 0.10\right)$ and IRQ and the social score $\left(t: 2.087^{* *} ; p: 0.04\right)$ for the other sectors.

Based on the reported results, $\mathrm{H}_{\mathrm{A}, 1}$ (Eqn 1) was rejected for the composite ESG score for the entire sample. Significant positive links were, however, noted for the ESG composite score on industry level and IRQ and the individual ESG scores. The regression results for the financial indicators for $\mathrm{H}_{\mathrm{A}, 2}$ (Eqn 2) and $\mathrm{H}_{\mathrm{A}, 3}($ Eqn 3$)$ are shown in Table 6 and Table 7.

Table 6 reveals that the TSR was negatively related to IRQ. Instances of negative market sentiment possibly occurred during the period under review. This result was, however, not significant after adjusting for heteroskedasticity. Marcia et al. (2015) likewise reported that CSR disclosures of JSElisted companies did not have a significant link with their share prices. In contrast, the sample companies with a high level of IRQ tended to have high EPS values. As managerial stewardship includes the protection and efficient application of resources on behalf of shareholders, the EPS ratio is deemed a key investor consideration (Mohon 1999). In contrast to the findings of Lee and Yeo (2016) and Barth et al. (2017), Table 6 shows no significant association between Tobin's $Q$ and IRQ. While an insignificant ROA result was reported for the considered companies, Buitendag et al. (2017) noted a significant negative relationship between profitability and IRQ, considering only the EY progress and excellent categories over a shorter time frame. Given the
TABLE 6: Regression analysis results for integrated reporting quality and financial performance.

\begin{tabular}{lccccc}
\hline Variable & $\begin{array}{c}\text { Regression } \\
\text { coefficient }\end{array}$ & $\begin{array}{c}\text { Standard } \\
\text { error }\end{array}$ & $\boldsymbol{t}$-value & $\boldsymbol{P r} \boldsymbol{\rangle}|\boldsymbol{t}| \boldsymbol{t}$-value adjusted for \\
heteroskedasticity
\end{tabular}

Note: Adjusted $R$-squared: 0.20 ; the quality of fit of the regression model was significant; fit of the model: $F 1.71^{*} ; d f 7,406$.

Preferred model: One-way fixed effects; test for fixed effects $(F): 18.27 * *$; Hausman test for random effects $(F): 16.55 * *$

Breusch-Pagan heteroskedasticity: 301.22***.

DPS, dividend per share; EPS, earnings per share; TSR, total share return; ROA, return on assets.

*, Significant at the $10 \%$ level; **Significant at the $5 \%$ level; ***, Significant at the $1 \%$ level.

TABLE 7: Regression analysis results for integrated reporting quality and leverage.

\begin{tabular}{|c|c|c|c|c|c|}
\hline Variable & $\begin{array}{l}\text { Regression } \\
\text { coefficient }\end{array}$ & $\begin{array}{l}\text { Standard } \\
\text { error }\end{array}$ & $z$-value & $\operatorname{Pr}>|z|$ & $\begin{array}{l}z \text {-value adjusted for } \\
\text { heteroskedasticity }\end{array}$ \\
\hline Intercept & -0.027 & 1.05 & $2.69 * * *$ & 0.01 & $2.664 * * *$ \\
\hline Leverage & 0.137 & 0.01 & 1.44 & 0.15 & $1.673 *$ \\
\hline WACC & -0.001 & 0.05 & -0.01 & 0.99 & -0.008 \\
\hline $\begin{array}{l}\text { Market } \\
\text { capitalisation } \\
(\log 10)\end{array}$ & -0.028 & 0.21 & -0.29 & 0.77 & -0.310 \\
\hline \multicolumn{6}{|c|}{$\begin{array}{l}\text { Note: Adjusted } R \text {-squared: } 0.02 \text {; the quality of fit of the regression model was significant; fit } \\
\text { of the model: Wald } 13.61^{* * *} \text {. }\end{array}$} \\
\hline \multirow{2}{*}{\multicolumn{6}{|c|}{$\begin{array}{l}\text { Preferred model: Random two-way; test for fixed effects }(F): 19.35^{* * *} \text {; Hausman test for } \\
\text { random effects }(F): 0.73 \text {. } \\
\text { Breusch-Pagan heteroskedasticity: } 269.96 * * * \text {. }\end{array}$}} \\
\hline & & & & & \\
\hline \multicolumn{6}{|c|}{ WACC, weighted average cost of capital. } \\
\hline
\end{tabular}

differences in the accounting determination of ROA on a sector level, this financial performance variable was omitted and the regression analysis was repeated. After adjusting for heteroskedasticity, the observed negative link between IRQ and TSR remained significant $(t:-1.929 * * ; p$ : 0.05).

As indicated in Table 7, a positive relationship emerged between the considered companies' level of IRQ and their leverage. Zhou et al. (2017) and Lee and Yeo (2016) also found that companies with better integrated reports used more debt capital. These results suggest that lenders have greater trust in companies with reliable credit histories and transparent disclosure (Lee \& Yeo 2016; Zhou et al. 2017). Companies with a high level of IRQ arguably experience pressure from lenders to enhance their disclosure given the considerable risks associated with high debt usage.

Based on the results reported in Table 6 and Table 7, $\mathrm{H}_{\mathrm{A}, 2}$ (Eqn 2) and $\mathrm{H}_{\mathrm{A}, 3}$ (Eqn 3) were accepted. Additional regression analyses were conducted to account for differences on industry level. The two largest sectors in this study (basic materials and financials) were again compared to the other sectors. After adjusting the results for heteroskedasticity, a significant link was detected between IRQ and leverage for the other sectors $\left(t:-2.312^{* *} ; p: 0.02\right)$. 


\section{Conclusion, limitations and recommendations}

The interrelations between IRQ, sustainability and financial performance of listed companies increasingly draw attention from scholars, practitioners, shareholders and other stakeholders. Following the arrival of IR as defined by the IIRC a decade ago, South Africa offers a suitable research context to investigate the extent to which this hybrid form of reporting succeeds in concretising relationships between IRQ, sustainability performance and financial performance. The authors of this study argue that integrated reports should prove their decision-usefulness by offering material ESG and financial information to capital providers.

The EY Excellence in Integrated Reporting Awards was employed as a proxy for IRQ. The sample comprised the largest companies listed on the JSE over the period 2013-2018 that were annually scored by EY. Composite and individual ESG scores were sourced from Bloomberg (2019). Various financial indicators were also incorporated to assess the hypothesised relationships. In addition to the governance scores, the panel regression results indicated significant positive relationships between a higher level of IRQ and higher environmental and social scores, which are vital considerations in the South African context. Significant positive links were also detected on industry level.

The descriptive statistics showed that low-quality (progress) reporters displayed higher levels of ROA and Tobin's $Q$ than companies with a high level of IRQ. In contrast, high-quality (excellent) reporters had higher EPS, DPS, TSR and debt usage in comparison to those ranked in the progress category. The question then arises whether IR truly convinces the providers of equity and debt capital of large locally listed companies' financial performance. Panel regression analyses were consequently conducted. Insignificant results were reported between the level of IRQ and all the considered financial variables except EPS and TSR (on industry level). The findings thus suggest that those companies with a high IRQ, and by implication their capital providers, were not per se rewarded in financial terms.

The best integrated reporters made greater use of borrowed capital than progress reporters. High IRQ could imply that more decision-useful and accountable information was offered to the providers of debt capital to locally listed companies. Companies that provide excellent integrated reports are likely to have a more reliable credit history, present a lower risk to lenders and arguably be strategically better positioned to decide on an optimal capital structure. The lack of a significant relation between IRQ and Tobin's $Q$ raises questions about the reliability of the reported asset values. As a result, companies are urged to offer greater clarity on the value of human capital and other intangible aspects in their integrated reports.
When investigating the impact of IRQ, previous researchers considered different components of the IIRC framework, including its content elements, principles and fundamental concepts. The apparent lack of recognition by investors may relate to how IRQ is defined (e.g. by the EY Awards scheme) and the possibility that even companies with a high level of IRQ still fail to effectively link sustainability performance with financial performance. Companies need to ensure that information related to the interconnectedness of their capitals is properly explained to gain substantive legitimacy. Confusion about target audience might result in a low IRQ. South African companies should ensure that they offer relevant information to their capital providers.

In line with De Villiers et al.'s (2017a) observation that legitimacy is a consequence of IR, whereas organisational features are determinants of IRQ, investors are encouraged to adopt a long-term investment focus. They should pressurise companies to enhance their transparency, decision-usefulness and accountability pertaining to the six capitals, instead of merely focusing on financial capital. Institutional investors need to engage more actively with companies to ensure that they deliver on expectations. Educators furthermore have an important role to ensure that future corporate leaders and investors are sufficiently informed of the interconnections between capitals and the relevance of sustainable value creation.

With respect to the study's limitations, the narrow focus on the JSE Top 100 companies and possible subjectivity of the EY assessors are acknowledged. It should also be noted that Bloomberg (2019)'s composite and individual ESG scores that were employed as proxies for sustainability performance were reflective of disclosure, but they did not necessarily reflect actual ESG performance. Investors are relying on various sources of information in their decisionmaking today. Future researchers could therefore adopt a broader approach to assess the role of IRQ by also scrutinising financial and sustainability reports, investor briefings, press releases and related online material. They can consider IR as an 'umbrella report for an organisation's broad suite of reports and communications' (International Federation of Accountants 2017) to offer a strategic entry point to gain insight into each company's specific context. More focus could be placed on sector-specific analyses by accounting for differences in the ESG practices and organisational complexity of companies. The role of intangible assets and human capital management warrants pertinent consideration. Future researchers could focus on banks and other financial companies in the advent of the fourth industrial revolution.

\section{Acknowledgements}

Prof. Martin Kidd for his assistance with the statistical analysis.

\section{Competing interests}

The authors have declared that no competing interest exists. 


\section{Authors' contributions}

N.M-K. conceptualised the article, wrote the results section and contributed to the literature review. C.T.v.d.L. contributed to the conceptualisation of the article, literature review and finalisation of the article.

\section{Funding information}

This research received no specific grant from any funding agency in the public, commercial or not-for-profit sectors.

\section{Data availability statement}

Data sharing is not applicable to this article as no new data were created or analysed in this study.

\section{Disclaimer}

The views and opinions expressed in this article are those of the authors and do not necessarily reflect the official policy or position of any affiliated agency of the authors.

\section{References}

Adams, C.A., 2015, 'The international integrated reporting council: A call to action', Critical Perspectives on Accounting 27(C), 23-28. https://doi.org/10.1016/j. cpa.2014.07.001

Adams, C.A., Potter, B., Singh, P.J. \& York, J., 2016, 'Exploring the implications of integrated reporting for social investment (disclosures)', The British Accounting Review 48(3), 283-296. https://doi.org/10.1016/j.bar.2016.05.002

Ahmed Haji, A. \& Anifowose, M., 2017, 'Initial trends in corporate disclosures following the introduction of integrated reporting practice in South Africa', Journa of Intellectual Capital 18(2), 373-399. https://doi.org/10.1108/JIC-01-2016-0020

Alrazi, B., De Villiers, C. \& Van Staden, C.J., 2015, 'A comprehensive literature review on, and the construction of a framework for, environmental legitimacy, accountability and proactivity', Journal of Cleaner Production 102(1), 44-57. https://doi.org/10.1016/j.jclepro.2015.05.022

Armstrong, P., Segal, N. \& Davis, B., 2005, 'Corporate Governance: South Africa, a pioneer in Africa', South African Institute of International Affairs, viewed 18 November 2018, from https://saiia.org.za/research/corporate-governance-southafrica-a-pioneer-in-africa.

Atkins, J. \& Maroun, W., 2015, 'Integrated reporting in South Africa in 2012: Perspectives from South African institutional investors', Meditari Accountancy Research 23(2), 197-221. https://doi.org/10.1108/MEDAR-07-2014-0047

Baboukardos, D. \& Rimmel, G., 2016, 'Value relevance of accounting information under an integrated reporting approach: A research note', Journal of Accounting and Public Policy 35(4), 437-52. https://doi.org/10.1016/j.jaccpubpol.2016.04.004

Barth, M.E., Cahan, S.F., Chen, L. \& Venter, E.R., 2017, 'The economic consequences associated with integrated report quality: Capital markets and real effects', Accounting, Organizations and Society 62(1), 43-64. https://doi.org/10.1016/j. aos.2017.08.005

Bernardi, C. \& Stark, A.W., 2018, 'Environmental, social and governance disclosure, integrated reporting and the accuracy of analyst forecasts', The British Accounting Review 50(1), 16-31. https://doi.org/10.1016/j.bar.2016.10.001

Bloomberg, L.P., 2019, Research domain. Software and database. New York, NY.

Buitendag, N., Fortuin, G.S. \& De Laan, A., 2017, 'Firm characteristics and excellence in integrated reporting', South African Journal of Economic and Management Sciences 20(1), a1307. https://doi.org/10.4102/sajems.v20i1.1307

Burke, J.J. \& Clarke, C.E., 2016, 'The business case for integrated reporting: Insights from leading practitioners, regulators, and academics', Business Horizons 59(3), 273-283. https://doi.org/10.1016/j.bushor.2016.01.001

Burlea-Schiopoiu, A. \& Popa, I., 2013, 'Legitimacy theory', in S.O. Idowu, N. Capaldi, L. Zu \& A. Das Gupta (eds.), Encyclopedia of corporate social responsibility, pp. 1579-1584, Springer-Verlag, Berlin.

Chang, C.M., 2016, Engineering management: Meeting the global challenges, 2nd edn., Taylor \& Francis, Boca Raton, FL.

Cheng, M., Green, W., Conradie, P., Konishi, N. \& Romi, A., 2014, 'The international integrated reporting framework: Key issues and future research opportunities', Journal of International Financial Management \& Accounting 25(1), 90-119. https://doi.org/10.1111/jifm.12015

Cho, C.H. \& Patten, D.M., 2007, 'The role of environmental disclosures as tools of legitimacy: A research note', Accounting, Organizations and Society $32(7-8)$, 639-647. https://doi.org/10.1016/j.aos.2006.09.009
Churet, C. \& Eccles, R.G. 2014, 'Integrated reporting, quality of management and financial performance', Journal of Applied Corporate Finance 26(1), 56-64. https://doi.org/10.1111/jacf.12054

Deegan, C. \& Unerman, J., 2011, Financial accounting theory, McGraw-Hill Education, Berkshire.

Demuijnck, G. \& Fasterling, B., 2016, 'The social license to operate', Journal of Business Ethics 136(4), 675-685. https://doi.org/10.1007/s10551-015-2976-7

De Villiers, C., Hsiao, P-C.K. \& Maroun, W., 2017a, 'Developing a conceptual model of influences around integrated reporting, new insights and directions for future research', Meditari Accountancy Research 25(4), 450-460. https://doi.org/ 10.1108/MEDAR-07-2017-0183

De Villiers, C., Rinaldi, L. \& Unerman, J., 2014, 'Integrated reporting: Insights, gaps and an agenda for future research', Accounting, Auditing \& Accountability Journa 27(7), 1042-1067. https://doi.org/10.1108/AAAJ-06-2014-1736

De Villiers, C. \& Sharma, U., 2017, 'A critical reflection on the future of financial, intellectual capital, sustainability and integrated reporting', Critical Perspectives intellectual capital, sustainability and integrated reporting',
on Accounting. https://doi.org/10.1016/j.cpa.2017.05.003

De Villiers, C., Venter, E.R. \& Hsiao, P-C.K., 2017b, 'Integrated reporting: Background, measurement issues, approaches and an agenda for future research', Accounting \& Finance 57(4), 937-959. https://doi.org/10.1111/acfi.12246

Dilling, P.F.A. \& Caykoylu, S., 2019, 'Determinants of companies that disclose highquality integrated reports', Sustainability 11(13), 1-31. https://doi.org/10.3390/ su11133744

Dumay, J., Bernardi, C., Guthrie, J. \& Demartini, P., 2016, 'Integrated reporting A structured literature review', Accounting Forum 40(3), 166-185. https://doi. org/10.1016/j.accfor.2016.06.001

Du Toit, E., Van Zyl, R. \& Schutte, G., 2017, 'Integrated reporting by South African companies: A case study', Meditari Accountancy Research 25(4), 654-674. https:// doi.org/10.1108/MEDAR-03-2016-0052

Eccles, R.G., Krzus, M.P. \& Solano, C.A., 2019, 'Comparative analysis of integrated reporting in ten countries', Social Science Research Network. http://doi. org/10.2139/ssrn.3345590

Eccles, R.G., Serafeim, G. \& Krzus, M., 2011, 'Market interest in non-financial information', Journal of Applied Corporate Finance 23(4), 113-127. https://doi. information', Journal of Applied Corporate
org/10.1111/j.1745-6622.2011.00357.x

EYGM Ltd., 2017, EY's excellence in integrated reporting awards 2017, viewed 12 February 2019, from https://greymatterfinch.com/pdf/EY_Top_100 Excellence_IR_Awards_2017.pdf.

García-Benau, M.A., Sierra-Garcia, L. \& Zorio, A., 2013, 'Financial crisis impact on sustainability reporting', Management Decision 51(7), 1528-1542. https://doi. org/10.1108/MD-03-2013-0102

Giamporcaro, S., Pretorius, L. \& Visser, M., 2010, Responsible investment: A vehicle for environmentally sustainable economic growth in South Africa?, Environment for Development Discussion Paper series, viewed 24 November 2019, from http:// www.efdinitiative.org/sites/default/files/efd-dp-17.pdf.

Higgins, C., Stubbs, W. \& Love, T., 2014, 'Walking the talk(s): Organisational narratives of integrated reporting', Accounting, Auditing \& Accountability Journal 27(7), 1090-1119. https://doi.org/10.1108/AAAJ-04-2013-1303

Horn, R., De Klerk, M. \& De Villiers, C., 2018, 'The association between corporate social responsibility reporting and firm value for South African firms', South African Journal of Economic and Management Sciences 21(1), a2236. https://doi. org/10.4102/sajems.v21i1.2236

International Federation of Accountants, 2017, Enhancing organizational reporting: Integrated reporting key, viewed 12 September 2019, from https://www.ifac.org/ system/files/publications/files/PPP8-Enhancing-Organizational-ReportingJan-2017.pdf.

International Integrated Reporting Council (IIRC), 2013, The international $\langle/ R>$ framework, viewed 25 November 2018, from https://integratedreporting.org/wp-
content/uploads/2013/12/13-12-08-THE-INTERNATIONAL-IR-FRAMEWORK-2-1. conte
pdf.

International Integrated Reporting Council (IIRC), 2019, Building momentum: IIRC Integrated Report 2019, viewed 03 November 2018, from https://integratedreporting. org/integratedreport2018/download/pdf/IIRC_INTEGRATE_REPORT_2018.pdf.

Jennings, M.M., 2003, 'A primer on Enron: Lessons from a perfect storm of financial reporting, corporate governance and ethical culture failures', California Western Law Review 39(2), 163-262.

Jermias, J., 2008, 'The relative influence of competitive intensity and business strategy on the relationship between financial leverage and performance', The British Accounting Review 40(1), 71-86. https://doi.org/10.1016/j.bar.2007.11.001

Klasa, A., 2018, 'Sustainable finance: Integrated reporting offers fix for "insufficient" status quo', Financial Times, 5 December, viewed 06 December 2018, from https:// www.ft.com/content/e0eb2a72-ddfb-11e8-b173-ebef6ab1374a.

Lai, A., Melloni, G. \& Stacchezzini, R., 2016, 'Corporate sustainable development: Is 'integrated reporting' a legitimation strategy?', Business Strategy and the Environment 25(3), 165-177. https://doi.org/10.1002/bse.1863

Lee, K-W. \& Yeo, G.H-H., 2016, 'The association between integrated reporting and firm value', Review of Quantitative Finance and Accounting 47(4), 1221-1250. https:// doi.org/10.1007/s11156-015-0536-y

Lindblom, C.K., 2010, 'The implications of organizational legitimacy for corporate social performance and disclosure', in R. Gray, J. Bebbington \& S. Gray (eds.), Social and environmental accounting, pp. 51-63, Sage, Los Angeles, CA.

Lopes, A.I. \& Coelho, A.M., 2018, 'Engaged in integrated reporting? Evidence across multiple organizations', European Business Review 30(4), 398-426. https://doi. org/10.1108/EBR-12-2016-0161 
Mahoney, L.S., Thorne, L., Cecil, L. \& LaGore, W., 2013, 'A research note on standalone corporate social responsibility reports: Signalling or greenwashing?', Critical corporate social responsibility reports: Signalling or greenwashing?', Critical
Perspectives on Accounting 24(4-5), 350-359. https://doi.org/10.1016/j.cpa.2012. Perspectiv
09.008

Malola, A. \& Maroun, W., 2019, 'The measurement and potential drivers of integrated report quality: Evidence from a pioneer in integrated reporting', South African report quality: Evidence from a pioneer in integrated reporting', South African Journal of Accountind
54.2019.1647937

Marcia, A., Maroun, W. \& Callaghan, C., 2015, 'Value relevance and corporate responsibility reporting in the South African context: An alternate view post KingIII', South African Journal of Economic and Management Sciences, 18(4), a1192. https://doi.org/10.4102/sajems.v18i4.1192

Melloni, G., Caglio, A. \& Perego, P., 2017, 'Saying more with less? Disclosure conciseness, completeness and balance in integrated reports', Journal of Accounting and Public Policy 36(3), 220-238. https://doi.org/10.1016/j.jaccpu bpol.2017.03.001

Mohon, R., 1999, Stewardship ethics in debt management, Springer, Dordrecht.

Müller, C., 2013, Confirming dividend changes and the non-monotonic investor revision of earnings persistence, Springer Gabler, Cologne.

Pucci, S., Cenci, M., Tutino, M. \& Luly, R., 2014, 'Intangible assets: Curren requirements, social statements, integrated reporting and new models', in $\mathrm{M}$. Russ (ed.), Value creation, reporting, and signalling for human capital and human asset, pp. 179-211, Palgrave Macmillan, New York, NY.

Setia, N., Abhayawansa, S., Joshi, M. \& Huynh, A.V., 2015, 'Integrated reporting in South Africa: Some initial evidence', Sustainability Accounting, Management and Policy Journal 6(3), 397-424. https://doi.org/10.1108/SAMPJ-03-2014-0018
Simnett, R. \& Huggins, A.L., 2015, 'Integrated reporting and assurance: Where can research add value?', Sustainability Accounting, Management and Policy Journal 6(1), 29-53. https://doi.org/10.1108/SAMPJ-09-2014-0053

Slack, R. \& Campbell, E., 2016, 'Meeting users' information needs: The use and usefulness of Integrated Reporting', in The Association of Chartered Certified Accountants, viewed 13 November 2018, from https://www. accaglobal.com/content/dam/ACCA_Global/Technical/integrate/pi-useusefulness-ir.pdf.

Solomon, J. \& Maroun, W., 2012, Integrated reporting: The influence of King III on social, ethical and environmental reporting: ACCA Research Report, The Association of Chartered Certified Accountants, London.

Stolowy, H. \& Paugam, L., 2018, 'The expansion of non-financial reporting: An exploratory study', Accounting and Business Research 48(5), 525-548. https://doi. org/10.1080/00014788.2018.1470141

Suchman, M.C., 1995, 'Managing legitimacy: Strategic and institutional approaches', Academy of Management Review 20(3), 571-610. https://doi.org/10.2307/258788

Van Bommel, K., 2014, 'Towards a legitimate compromise? An exploration of integrated reporting in the Netherlands', Accounting, Auditing \& Accountability Journal 27(7), 1157-1189. https://doi.org/10.1108/AAAJ-04-2013-1309

Van Zijl, W., Wöstmann, C. \& Maroun, W., 2017, ' Strategy disclosures by listed financial services companies: Signalling theory, legitimacy theory and South African integrated reporting practices', South African Journal of Business Management 48(3), 73-85. https://doi.org/10.4102/sajbm.v48i3.37

Zhou, S., Simnett, R. \& Green, W., 2017, 'Does integrated reporting matter to the capital market?', ABACUS 53(1), 94-132. https://doi.org/10.1111/abac.12104 